\title{
THE REGIONAL DIMENSION OF THE SOCIO-POLITICAL URBAN-RURAL CONFLICT IN SLOVAKIA
}

\author{
MARTIN PLEŠIVČÁK \\ Comenius University, Faculty of Natural Sciences, Department of Human Geography and Demography
}

\begin{abstract}
Political behaviour of citizens is traditionally formed by a wide range of factors that influence their voting decision in the election. Dichotomy of both the space and society into the town and the countryside generates different election results constantly. A key aim of this paper is to assess the extent of rurality concerning the electoral support of relevant political parties operating on the Slovak political scene after the groundbreaking elections held in 1998 until ballots of 2010 not only at national, but also at the regional level. Evaluation of level and dynamics in socio-political cleavage between rural and urban space is one of the most important research ambitions of this study. We shall note the position of particular regions in Slovakia in terms of size and acceleration of the conflict and try to categorize them according to the similarity in values of indicators characterizing this social discrepancy. On the basis of found facts, we shall appraise the electoral success of political parties in urban and rural environment and compose the regional typization of Slovakia concerning the party representatives of urban and rural environment. Finally, we shall evaluate the potential of the regions to be future outbreak sites of latent cleavage influencing their differential political inclination.
\end{abstract}

Key words: socio-political conflict, political party, urban, rural, functional urban region

\section{Introduction}

Social cleavage characterized by a conflict between the town and countryside was firstly identified by Lipset and Rokkan in the late 1960s. These authors have defined the conflict lines emerging from structure of social-economic relations formed between groups of political community. They stated four long-term social cleavages regarded as a consequence of both the industrial and national revolution: employers vs. workers, urban vs. rural, state vs. church and centre vs. periphery. Half a century later, these social conflicts still affect political behaviour of electorate.

Urban-rural cleavage played a significant role in politics already at the end of the nineteenth century. Both the culminating industrialization and growth of international trade generate increasing tension between farmers in the countryside on one hand and traders together with industrialists in the urban space on the other. Most researchers draw attention to the decrease in importance of this conflict in Western Europe at the beginning of last century, i.e. in the countries already highly industrialized at that time. Northern European countries declared a remarkable influence of this factor on domestic political affairs even in the middle of the twentieth century. Today it is possible to watch the socio-political conflict between the town and countryside in post-socialist countries of Central and Eastern Europe and less developed countries, where the process of industrialization has not been clearly completed yet. In the case of former Eastern Bloc countries, agrarian parties enjoyed considerable popularity even at the end of the nineties of the last century (Stoll
2004). Lipset and Rokkan (1967) stated that the social conflict of this nature is typical of social tension emerging just in transforming societies. Ideological dimension of the conflict between the rural and urban way of life is associated with the issue of state subsidies for farmers, rural development and land use management as well.

Therefore, agrarian parties were developed as guardians of the rural economy against urban industry dealing with the tariff level for agricultural products. However, this does not mean that the peasant parties necessarily arise wherever the farmers live. Other parties may also defend the interests of the countryside, because the division of territory (or society) in urban and rural space overlaps with other social cleavage, such as "state vs. church" conflict or "centre vs. periphery" conflict. Therefore, Christian democratic parties or parties of ethnic minorities may also address the rural part of the electorate, although these parties often represent rather the cultural identity then the economic interests of the agriculture sector. At the turn of the century, Zarycki (2000) applied classic Lipset-Rokkan model to conditions of transforming post-communist societies of Central and Eastern European countries considering the historical context of socio-political division in Poland. In 2003, Johannsen conducted an extensive research concerning the development and nature of urban-rural conflict after 1989 in 21 post-communist countries of Central and Eastern Europe. According to results of this study, urban population claims a higher support to the market and prefers limitation of the state's role in the process of resources distribution in most countries of the region. This result 
was expected, since the loss of the rural economy in the transition period was significantly higher compared to the town (Lemel 1998; Lerman 1999; Swinnen 1999).

Issue of socio-political cleavage between town and the countryside has been properly covered by Czech and Slovak political scientists, as well. Kostelecký and Čermák (2004) dealt with the socio-spatial changes occurred in metropolitan areas of the largest cities in Czech Republic and assessed their impact on political behaviour of particular region. Similar research was also conducted by Kyloušek (2007), who tried to find linkage between spatial distribution of socio-demographic and electoral characteristics on the example of Brno and its hinterland. In 2009, Kyloušek and Pink compared territorial pattern of electoral support for main socio-democratic party in Czech Republic on one hand (ČSSD) and Slovakia on the other (Smer-SD) regarding its urban-rural context, too.

Slovak sociological, political and geographical research has also focused on the issue of identifying the factors influencing the electoral decisions of voters in the countries of the former Soviet bloc with special attention to the political behaviour of electorate in the Slovak Republic, of course. The contribution of these very often cooperating disciplines using mutual piece of knowledge is greatly appreciated mainly due to their efforts to affect the partial socio-political conflict lines dividing the Slovak society during the transition period after 1989 on the one hand and also reflecting the heritage of the historical development of society in Slovakia on the other. Study of sociologist Krivý (2000) is considered as one of the most valuable work within domestic political science dealing with the voting preferences of different groups existing in Slovak society. In this analysis, he sufficiently emphasizes the geographical context of given issue through the differential electoral pattern of people living in both the urban environment and rural communities as well. This voting preferential peculiarity is associated with the size structure of territory where they live in, thus quite substantial differences in the votes of urban and rural voters can be observed. Such as the polish political scientists in the case of our northern neighbour did (Shabad, Slomczynski 1999; Zarycki, Nowak 2000), Krivý (in relation to the Slovak reality) comes to the same finding that the urban environment is negatively set towards the values of egalitarianism, paternalism or authoritarianism, which are typical mainly for rural voters. According to his findings, value and ideological discrepancy between urban and rural electorate is more perceptible than the social status of the population or its level of education evaluated in the context of these two different social worlds.

More than decade later, Madleňák (2012) notes that the direct institutionalized link between latent socio-political cleavage of electorate living in urban and rural communities and crucial political formations in the state is constantly missing. Therefore, the party system in Slovakia still lacks urban-rural cleavage and overlaps with other conflict lines that shape relationship between voters and political elites (e.g. mečiarizmus-antimečiarizmus, conservative-liberal, socio-economic or nationalistic), in fact.

\section{Methodological issues}

In addition to assessing the differences in support of major political parties in the urban and rural areas at statewide and regional level as well, the essential part of our research is to determine the regional disparities in urban-rural profile of political parties in Slovakia during the first decade of the new millennium. For this purpose it is necessary to choose such a concept of territorial units, which would accept the preferential uniqueness of individual regions given by long-term historical development of our society and its parts as far as possible. Since there are not spatial units defined in Slovakia, which would reflect an intra-territorial cohesion of electoral support, therefore in order to evaluate the urban-rural divergence the concept of functional urban regions ("FUR" in short) seems to be the most acceptable because the urban and rural space is delimited on the basis of real socio-spatial (rather than administrative or statistical) criteria, there. Although this territorial concept was constructed based on apolitical criteria non-reflecting the electoral behaviour of those living in the territory, for analysis with similar ambitions the consistency in definition of urban and rural space might be important indicator of urban-rural voting preferential disproportion between urban and rural environment. They represent the most real territorial units of the regional level reflecting the long-term link formed between the centre and its hinterland. In Slovakia, this spatial concept was applied by Bezák (2000), who identified two alternative ways of daily urban system (or functional urban regions) delimitation in his study. For the empirical part of this paper, we will deal with the level "A" consisting of 51 regions. In order to thorough depiction of studied relationships existing at regional level, we will also use the traditional historical names of Slovak regions in some sections of the text.

The data structure that was utilized in mathematical calculations and statistical procedures carried out in the empirical part of this paper also deserves our attention, i.e. results of four elections to the parliament in total at the municipal level conducted in Slovakia during the period of 1998-2010. Diapason of political parties under study consisted of those, which after 1998 became at least once the part of the National Council of Slovak Republic and thus represented a significant number of Slovak voters in the political field during this period. The group of analyzed political parties was represented by (12): People's Party - Movement for a Democratic Slovakia (L'S HZDS), Hungarian Coalition Party - Magyar Koalíció Pártja (SMK-MKP), the Slovak Democratic and Christian Union - Democratic Party (SDKÚ-DS), Slovak National Party (SNS), Direction - Social Democracy (Smer-SD), 
Christian Democratic Movement (KDH), the Party of Civic Understanding (SOP), Party of Democratic Left (SDL'), the Communist Party of Slovakia (KSS), Alliance of New Citizen (ANO), Freedom and Solidarity (SaS) and Most-Híd (Most-Híd). Election results of given party were taken into consideration just in the case if the party gained at least $5 \%$ of the votes cast in the ballots that guaranteed the representation of this party in the National Council. SNS in election of 2002 was only exception, when its electoral gain was added together with votes for PSNS (partisan SNS voter elected either SNS or PSNS due to the split of Slovak nationalists in that ballots) and also in the case of LS-HZDS and SMK-MKP (political parties traditionally active in domestic political scene) that only slightly did not exceed the 5 -percent quorum required to enter the parliament at elections in 2010.

In this paper, rurality index of party's electoral outcomes $\left(\mathrm{R}_{\mathrm{i}}\right.$ in short) was the main indicator evaluating the urban-rural profile of the political party at national and regional level. This rate represents the ratio between the share of the votes gained by party in rural environment and the share of its electoral result in urban areas at given election during the period of 1998-2010. The higher the number than 1 is, the higher the rurality of party's electoral gain is and thus in terms of its electorate support it might be seen more rural. On the contrary, value lower than 1 indicates the urban character of the party's electorate. Thus, the lower these values below the number 1 are, the more urban this party is considered to be. In addition to this indicator of urban-rural cleavage, Krivý (1999) in his work applied slightly different coefficient, which expresses the same relationship, but seen from a position of urban voters. Method of delimitation of rural and urban space within particular regions of Slovakia was based on statutory criterion of the town and countryside definition. Of all more than 2900 municipalities in Slovakia, exactly 138 with the status of town was considered to be urban electoral basis, remaining ones represented the rural part of electorate.

The difference between rurality index of parties with the highest and the lowest value of this variable in the particular election is understood as the size (level) of urban-rural conflict in given region. The greater this difference is, the more significant socio-political conflict between urban and rural space can be expected, and vice versa. Average value for the whole period under study is used.

Acceleration of regional urban-rural conflict is defined as a growth in size of this cleavage in the region during the period of 1998-2010 (the growth rate regarding the level of values observed at the beginning and end of the period). If this rate reaches values higher than 1 , then there is a strengthening of socio-political conflict between the town and countryside in given territory, if less than 1 , the urban-rural cleavage is weakening in particular region. In order to catch the short-term inter-electoral change in socio-political urban-rural cleavage, we will also regard the growth rate from one election to the other and calculate its average value for the whole period.

Integral indicator taking into account both the size and growth rate of socio-political conflict between urban and rural electorate can be seen as a potential of urban-rural conflict line, which reflects the history of socio-political cleavage between these two very distinct social environments and allows estimating his future character at the same time. To the greatest objectivity in assessing process of the size and acceleration in urban-rural conflict not only for the region, but also in inter-regional comparison, the values of these two indicators were appraised by three different multi-criterion evaluation methods (ranking method, point method, factor comparison method). The final ranking of regions evaluated based on the potential of socio-political urban-rural conflict is to be determined following the average ranking for all three utilized methods.

In order to assess the regional size and growth rate of urban-rural conflict, the regional typization was composed, which divided territorial units into four different categories based on achieved values of these two variables. The overall level of urban-rural conflict in the region during the reporting period 1998-2010 was calculated as the average size of the regional socio-political conflict between the town and countryside in all elections under consideration. Given party had to obtain at least $5 \%$ of all votes cast at ballots in the region. The first group (type A) includes those regions which had above-average size of urban-rural conflict compared to the state-wide mean and recorded growth in the level of this conflict at the same time (growth rate greater than 1 ). The second regional type (type B) consists of those regions where an above-average socio-political conflict between urban and rural votes was observed, but it was weakening during the period (growth rate less than 1). Territorial units typical of below-average but strengthening urban-rural conflict in the period of 1998-2010 form the third category (type C). The last group of the regions (type D) was characterized by below-average socio-political conflict between urban and rural electorate, which was even weakening during the period under study.

Regional typization of Slovakia according to the longterm party representatives of the urban-rural conflict posed the last phase of the empirical work. In composing of this typization, the party's electoral gain of more than $5 \%$ of the valid votes cast at ballots at least in three of four analysed elections was condition to being party representative of this conflict. This measure reduced the number of political parties to 6 (LS-HZDS, SMK-MKP, SDKÚ-DS, SNS, Smer-SD and $\mathrm{KDH}$ ), while remaining 6 political parties did not meet this condition (SDL, SOP, KSS, ANO, SaS and Most-Híd). In addition to this term, the party of the first group had to get at least $5 \%$ of total votes cast at all four polls in a particular region, too. This took into account the regional peculiarities in the electoral gains of the parties and prevented the situation of 
being party representative of urban or rural environment despite the marginal electoral support in given region. Then, the political representative of urban electorate was regarded that party, which fulfilled all above-mentioned conditions and also achieved the lowest rurality index among all parties under consideration during the period we studied. On the other hand, the party with the highest rurality index of own election results was seen as a representative of the rural voters within the socio-political urban-rural conflict.

\section{Results}

\subsection{Size of socio-political urban-rural conflict and its regional particularities}

In regions with relatively little difference between the electoral behaviour of urban and rural population, it can be assumed a low level of socio-political conflict between urban and rural environment and vice versa. In this section, we will focus on differentiation of Slovakia assessed by this criterion in the period of 1998-2010, when four elections to the National Council of the Slovak Republic were held. We will take a look not only at size of the investigated socio-political cleavage of regions dividing themselves into the urban and rural part, but not forget to comment on the development of this conflict during the period under study (Table) as well.
Between 1998 and 2010, SMK-MKP and SDKÚ-DS have been profiled as political parties characterized by the deepest discrepancy in votes considering its urban-rural context at state-wide level. First mentioned party has been gaining mainly from rural environment of southern part of the country, whereas the latter one has been markedly dependent on support springing from urban space of the most urbanised regions of the state. In spite of that divergence, these two parties have been collaborating not only within the national political disputes, but even in government for a long time, which can be thought as evidence confirming the weakness of urban-rural conflict in the crucial socio-political topics in Slovakia. However, remarkable rurality of SMK-MKP's election outcomes is given by territorial distribution of Hungarians occupying the southern low-urbanised regions of the country. Therefore, its greater electoral gains in countryside are mainly due to spatial composition of ethnic structure in Slovakia rather than defending the real values traditionally peculiar to rural communities and their economic basis (support to agriculture). Smer-SD, KSS and SNS can be regarded as parties having very similar ratio of their election outcomes in both studied environments. It is interesting that contemporary governing party has taken the huge number of voters from L'S-HZDS characterized by striking rurality and therefore Fico's party changed it profile from moderately urban to slightly rural over decade.

Assessing the global state of this issue, we can conclude that the studied conflict weakened at the national

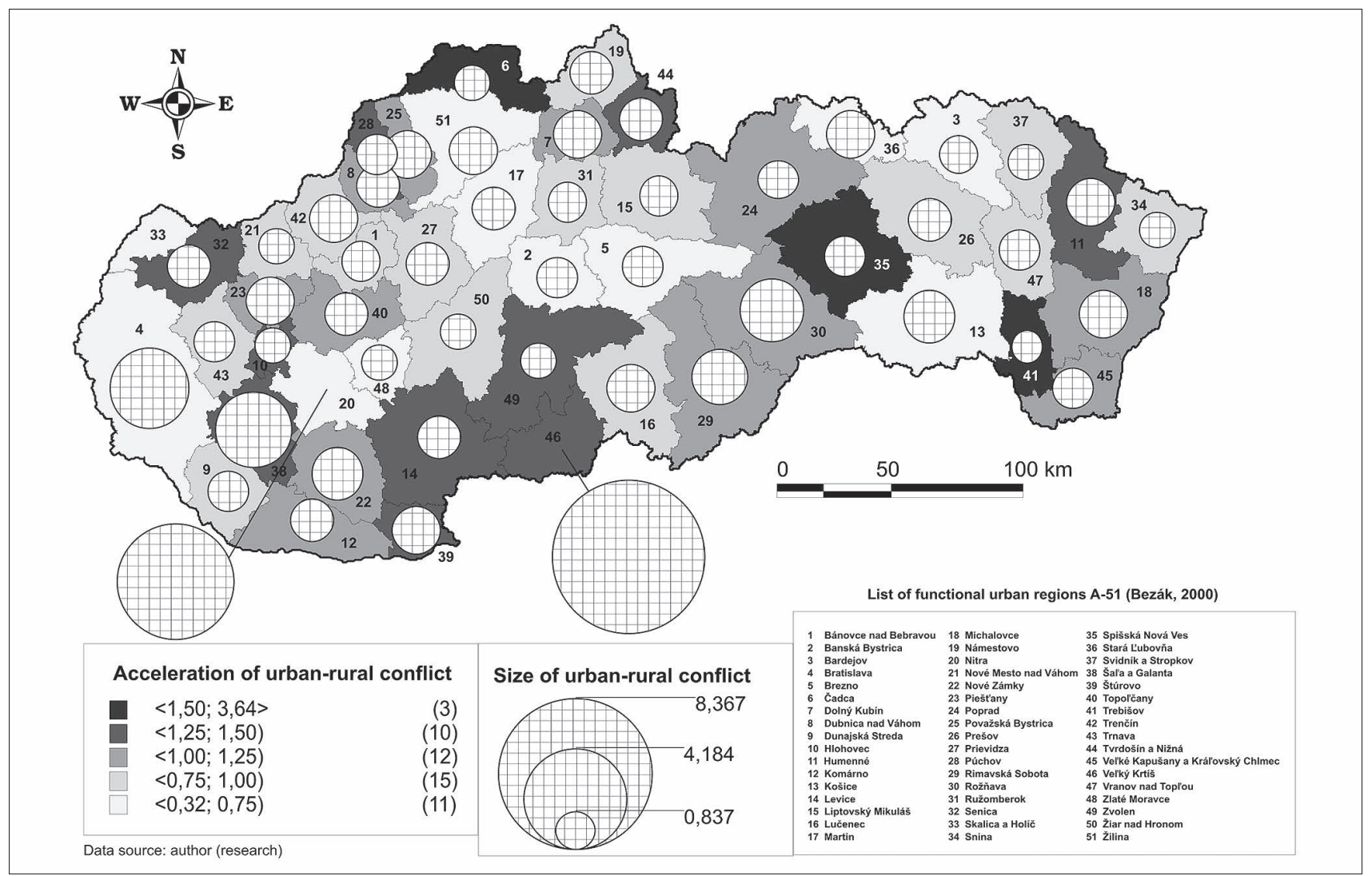

Fig. 1 Size and acceleration of socio-political urban-rural conflict in particular regions of Slovakia based on parliamentary election results in period of 1998-2010 
level between 1998 and 2010. The most significant socio-political fragmentation of society based on differences in electoral preferences of urban inhabitants on the one hand and of the countryside on the other was occurred in groundbreaking parliamentary elections held in 1998. Conversely, the highest degree of similarity between the election results of urban and rural space was recorded on the occasion of the Slovak parliamentary elections conducted in 2010. Thus, research results confirm that the elections to the National Council of the Slovak Republic in 1998 are rightfully marked as the battle between the town and countryside reflecting significant disparity in political behaviour of these two specific environments then. However, if we would not consider the socio-political cleavage between urban and rural voters in the southern parts of Slovakia given firstly by ethnic composition of the local population (typical of high territorial concentration of ethnic Hungarians), then we could regard elections taking place in 2002 as the most important fight of real urban and rural values at all.

During the period under study, the most significant socio-political cleavage between rural and urban electorate was found in regions of Vel'ký Krtíš (SMK-MKP as rural, Smer-SD as urban political representative), Nitra, Bratislava, Šala and Galanta, Rožňava and Rimavská Sobota (in all of these five regions, SMK-MKP vs. SDKÚ-DS), where the difference in rurality index of votes gained at ballots by relevant parties with the lowest and the highest value exceeded the level of 1.500 (Figure 1). On the other side, election results followed in urban and rural space were the most similar in the regions of Skalica and Holíč, Trebišov, Zvolen, Nové Mesto nad Váhom (in these four regions, KDH vs. SDKÚ-DS), Svidník and Stropkov, Snina, Hlohovec, Čadca, Zlaté Moravce and Žiar nad Hronom (in all of these six regions, LS-HZDS vs. SDKÚ-DS), where the numerical value of the socio-political discrepancies in political preferences of these two specific environments ranged below 0.750 . Nature of electoral support manifested by the town and countryside can be regarded as significantly different in several regions located in the south and southwest, while a very similar in some border regions of eastern Slovakia, in the central part of the state in Podpolanie region, in the north of Tekov region and Hont region, in Kysuce region and populationally and in territorially smaller regions situated in the west of the country.

\subsection{Development of socio-political urban-rural conflict and its regional particularities}

The acceleration (development) of examined socio-political conflict in urban and rural votes in individual regions of Slovakia is quantified by growth index concerning this electoral phenomenon. Comparing the first and the last year of the period under study, this kind of socio-political cleavage deepened the most in the regions of Trebišov, Spišská Nová Ves and Humenné locat- ed in eastern Slovakia, Čadca, Tvrdošín and Nižná in the north-western part of the country, Zvolen and its catchment area situated in the central part of the republic and Senica, Šala and Štúrovo and Galanta lying in the west of the state, in which the monitored discrepancy between urban and rural political inclination increased more than a third. In Trebišov region, this cleavage rose even by 3.5 times. On the other hand, the most significant decline occurred in the regions of Bratislava, Nitra and Skalica and Holíc located in the western part of the country, in the regions of Banská Bystrica and Brezno situated in the central Slovakia and Košice, Stará Lubovňa, Bardejov and their catchment areas lying in the East. Daily urban systems of Trenčín, Považská Bystrica and Dubnica nad Váhom situated in Považie region, Bánovce nad Bebravou, Trnava and their catchment territories located in western Slovakia, eastern regions of Vranov nad Toplou, Prešov and Vel'ké Kapušany and Královský Chlmec, Námestovo in Orava region and Žiar nad Hronom with its catchment area lying in the central part of the Slovak Republic can be considered as the parts of country showing a relatively stable level of socio-political cleavage between urban and rural population expressed through the electoral votes of people living in these two relatively distinct environments, where the growth index in mentioned conflict stabilized in the range of $0.90-1.10$ during the reporting period.

If we considered growth rate from one election to the other and made its average during the whole period under study, the results would change just slightly. The most significant increase in discrepancy between urban and rural election outcomes was identified in the regions of Trebišov, Humenné and Spišská Nová Ves situated in the east, Vel'ký Krtíš and Rožňava located in the southern part of central Slovakia, Čadca in the very north-western corner of the country, Nové Zámky, Štúrovo and in the region of Šala and Galanta lying in the south-western Slovakia, Zvolen in the middle part, and in the regions of Senica and Hlohovec that could be found in the western side of the Slovak Republic, where the average growth index regarding inter-electoral changes in socio-political urban-rural cleavage was keeping above level of 1.10. On the other hand, the most similar election results regarding their urban-rural context emerged in the regions of Bratislava, Skalica and Holíč, and Nitra situated in the western part of republic, Košice and Bardejov lying on the opposite side of the country, Brezno and Banská Bystrica in the central part of the Slovak Republic, and in the region of Stará Lubovña located in the north, where inter-electoral growth index was lower than 0.90. Eventually, FUR of Trnava lying in the western part of Slovakia, Trenčín and Považská Bystrica in Považie region, Ružomberok in Liptov region and Námestovo in Orava region (both situated in the north) posed the territories with the most stable voting preferential conflict between the town and countryside in the Slovak Republic.

In general, the value gap between the town and countryside manifested by a specific political behaviour of 
their inhabitants was the most pronounced in those regions of the country, which was typical of a high geographical concentration of Hungarians especially in the rural areas, whereas the urban environment is characterized by a significant representation of citizens with Slovak ethnicity, there. Conversely, the lowest socio-political conflict between the electorate of urban and rural communities was found in those parts of Slovakia, which had similar socio-economic characteristics affecting the political dimension of the whole region, too. In terms of spatial context of the Slovak Republic, the regional pattern regarding the level of socio-political cleavage between urban and rural environment can be considered as a long-term valid. Ongoing process of suburbanization typical for the largest towns in Slovakia mitigating the socio-political conflict between the town and countryside might be seen as a valuable piece of knowledge regarding this analysis.

In assessing the global state of investigated issue we can conclude that voting preferential conflict between urban and rural voters weakened at the national level between 1998 and 2010. The most perceptible socio-political fragmentation of society based on discrepancy in electoral decision making of urban inhabitants on the one hand and people living in the rural communities on the other was observed in groundbreaking parliamentary elections of 1998. Conversely, the highest degree of similarity between the election results recorded in the town and countryside was identified at the end of research period (in the case of 2010 elections). Thus, findings of this analysis testified that the parliamentary elections in 1998 often named as both the struggle between the town and countryside and victory of urban electorate over the rural voters confirm the strong cleavage in political behaviour of these distinct environments within the ballots held 14 years ago. The second highest socio-political conflict between urban and rural population was registered for the elections to the National Council of the Slovak Republic in 2006 when after eight years of right-wing government the coalition of Smer-SD, LS-HZDS and SNS came to power. However, if we don't consider the socio-political cleavage between urban and rural space in southern parts of Slovakia typical of high territorial concentration of the Hungarians, which is given mainly by the geographic composition of the local ethnic groups, then the elections in 2002 could be marked as the most important battle between the urban and rural values.

\subsection{Regional typization of Slovakia according to size and acceleration of socio-political conflict between urban and rural environment}

Based on the achieved level and development of socio-political conflict between urban and rural voters, a typization describing the regional pattern of this issue was designed, which can be understood as a synthetic tool comprehensively assessing the degree of (dis)similarity of regional electoral outcomes in the space-time context. According to size and acceleration of electoral cleavage between the town and countryside, given parts of Slovakia were divided into four categories (Figure 2).

The first of regions (15) are those with above-average level of socio-political cleavage between rural and urban electorate, which simultaneously recorded a strengthening of this conflict during the reference period of 1998-2010 (type A). The spatial pattern of this type is characterized by a considerable territorial compactness, since there is a continuous belt of regions located mainly along the southern border of the Slovak Republic. However, representation of this category was also observed in the western (regions of Pieštany, Senica), north-western (regions of Považská Bystrica, Dolný Kubín and Tvrdošín and Nižná) and eastern part of the country (regions of Humenné and Michalovce).

The second category consists of regions that manifest an abnormally high socio-political conflict between urban and rural communities, but losing on its intensity at the same time (type B). This is the least numerous group (9 regions) but having a relatively high population size of spatial units falling into. In this category, two cities of Bratislava and Košice and "big" towns in Slovakia (Nitra, Trenčín, Žilina, Martin) are also included. Spatially

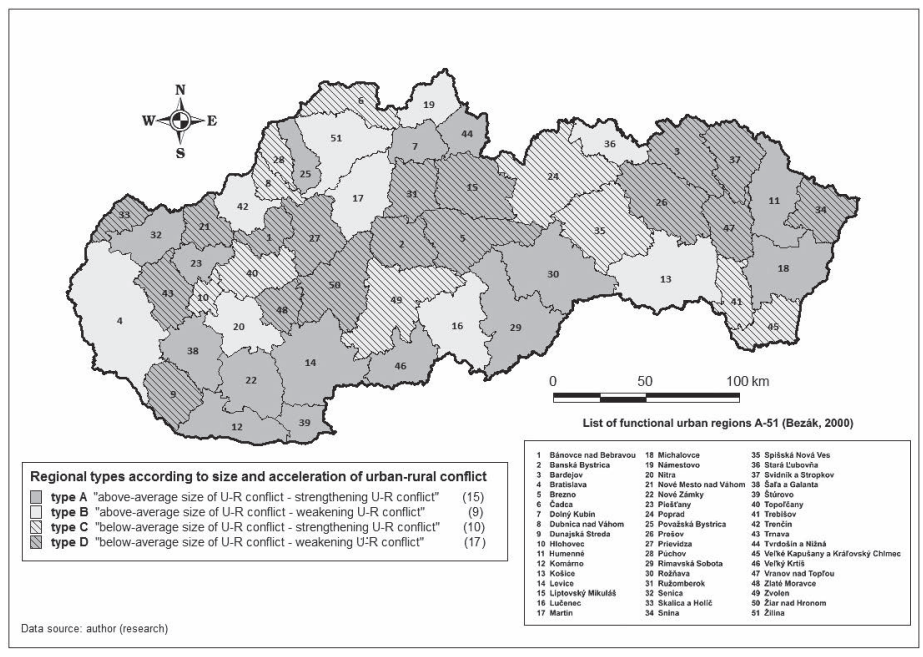

Fig. 2 Typization of Slovak regions according to size and acceleration of socio-political urban-rural conflict based on parliamentary election results in period of 1998-2010 
compact concentration of regions with above-average but declining socio-political cleavage of urban and rural voters was identified in the north-western skirt of the Slovak Republic. Behind the mitigating of discrepancy between urban and rural electoral mood in these regions we can find current process of suburbanization concerning the biggest towns and cities in Slovakia, since a significant share of urban population have started to occupy an attractive area of rural municipalities located in their hinterlands.

Almost the same number of spatial units (10) is grouped into the following category, which is common for regions with below-average but strengthening size of socio-political conflict between urban and rural electorate emerged in the analyzed period (type $\mathrm{C}$ ). This regional type does not pose a spatially compact belt. His territorial representatives can be found mainly in the regions of Považie, Kysuce, Tatras, Spiš, Podpolanie and in the southern part of Zemplín region as well. In the regions of Hlohovec and Topolčany situated in western Slovakia, below-average but gradually accelerating socio-political cleavage between urban and rural environment was also detected.

The last, and the most numerous category of spatial units (17) grouped on the basis of a relatively weak socio-political conflict between the town and countryside consists of a third of all Slovak regions (type D). These territories are characterized by a high and increasing similarity in the election results recorded in urban and rural environment during the period. Low voting preferential conflict in urban-rural division of space characterized by its further weakening was found in the regions of Šariš, Liptov, Horehronie, in the northern part of Tekov region, in the Horná Nitra region and in several parts of western Slovakia (in the regions of Dunajská Streda, Trnava, Skalica and Holíč, Nové Mesto nad Váhom, Bánovce nad Bebravou and Zlaté Moravce).

\subsection{Regional typization of Slovakia according to party representatives of socio-political conflict between urban and rural environment}

In the following part of contribution, we will focus on regional typization based on the existence of political parties representing the socio-economic interests of the people living in both the towns and cities on the one hand and the rural communities on the other in the long term.

In terms of political parties representing the urban or rural voters in the individual parts of the country, we came to typization consisting of four types of regions. During the period of 1998-2010, Mečiar's LS-HZDS and Dzurinda's SDKÚ-DS was crystallized as the most abundant type of party representatives covering the socio-political conflict between the town and countryside in functional urban regions of Slovakia, which embodied the greatest issue and value rivals in the field of domestic and foreign policy as well. This kind of urban-rural political conflict was recorded in 27 of 51 regions, which is peculiar to the most of central and north-eastern Slovakia (Figure 3). From the political geography point of view, it is concerning the regions generally regarded as the traditional cores of electoral support declared for LS-HZDS, whereas its political opponent is reliant on the urban environment in all regions of Slovakia, in fact. However, this does not mean that party of Vladimír Mečiar did not gain the considerable number of votes in the town of these regions at all. But in this case, electoral support appeared in the urban environment was overlaid the most just by the electoral gains coming from the rural environment of this regional type. The second most numerous type of regions (11) represented by both the SMK-MKP as a party of the Hungarian minority living in Slovakia, which is understood as a rural political representative in this context and the SDKÜ-DS shielding the interests of the urban electorate, is geographically concentrated in the south-western part of the country and southern territories located in the eastern half of Slovakia, too. In these regions of Slovakia, above-mentioned SMK-MKP detected its even highest voting support, which is especially dependent on the geographic composition of the Hungarians living there. This population group is typical of relatively strong rural character of its spatial distribution, which is significantly reflected in election results of SMK-MKP. Among all political parties, right-wing SDKÚ-DS relies the most on the votes cast at ballots by urban voters.

Socio-political conflict having reflection in the electoral inclination of the town and countryside characterized by the most prevailing rural support of $\mathrm{KDH}$ and striking share of urban votes for SDKÜ-DS is connected with strong spatial dispersion of regions representing this urban-rural cleavage type. Unlike the previous two types (L'S-HZDS vs. SDKÚ-DS and SMK-MKP vs. SDKÚ-DS), regions of KDH vs. SDKÚ-DS do not pose a compact spatial belt, which indicates a geographical randomness of their occurrence. However, regions of this type are located in the western half of the Slovak Republic more often ( 8 of 10 in total), while the coherent strip of them might be identified in Orava region and in the western part of Liptov region as well.

In the case of the last regional type, we can talk about "specific conflict" since its political representatives comprise the unique couples in the country. Vel'ký Krtíš with its catchment area located in the south of central Slovakia is the first region of this type. In addition to the greatest size of socio-political conflict between urban and rural environment, the region is characterized by an atypical twosome of party representatives. The region's rural area is inherently important to the electoral success of SMKMKP, while the town supports the Smer-SD differential in political and value manner in a large extent. As was mentioned earlier, this situation is caused by a unique ethnic composition of the region. In terms of ethnic representation, the local countryside is inhabited mostly by Hungar- 
ians, whereas the towns of Velký Krtís and Modrý Kameň are significantly Slovak. Therefore, the studied conflict is based rather on ethnicity than different urban and rural values. However, it should be mentioned that the typical representative of urban voters in other parts of Slovakia (SDKÚ-DS) had only a slightly higher rurality index of its electoral gain in the reporting period 1998-2010 compared to the party of Robert Fico, there.

Regional type of KDH vs. SNS refers to the category regarding the specific couples of socio-political cleavage between the town and countryside, as well. This kind of socio-political conflict was observed only in the region of Tvrdošín and Nižná situated in Orava, which is traditionally typical of significantly rural votes cast for $\mathrm{KDH}$. Finding on the greatest share of urban ballots registered in regional electoral gain of SNS is quite surprising. This is due to several reasons. The most pragmatic cause is that the right-wing political parties (e.g. SDKÚ-DS or SaS) enjoy a very similar popularity in both urban and rural environment there, which has kept their overall rurality index very close to value 1 . In the case of SNS, a much larger difference between the party's electoral outcome in the town on the one hand and countryside on the other (in favour of the urban space) is to be expected.

The town of Púchov with its catchment area poses the last region included in the category of a specific conflict covering the socio-political differences between urban and rural voters. After the parliamentary elections of 1998, Ján Slota's party (nationalistic SNS) was the political formation relying the most on the electoral votes coming from the rural environment of the region, whereas the SDKÚ-DS as a historic leader of the right wing was the party, whose regional election result was primarily built up on the electoral support flowing from the urban space.

\subsection{The potential of Slovak regions to be a future hub of socio- political conflict between the town and countryside}

To assess the potential of socio-political conflict between urban and rural electorate on the basis of its aver- age level and trend observed at the regional level for more than a decade (1998-2010) is the final ambition of this contribution. Such information defining the conditions of its future course tells about the possibilities of its further development in individual parts of the country. The size and growth index of socio-political regional cleavage manifested through the urban and rural electoral choices can be seen as the factors determining its character at the upcoming parliamentary elections.

Regions of southern and south-western Slovakia are considered as the territorial units with the highest potential to be future centres of social splitting based on different political inclination of urban and rural environment (Table 1). In functional urban regions of the Velký Krtîš, Rimavská Sobota and Rožňava located in southern Slovakia, of Štúrovo, Nové Zámky, Šala a Galanta, Nitra and Senica in the western part of the country, of Čadca, Tvrdošín and Nižná in the northwest and of Spišská Nová Ves, Humenné and Trebišov situated in eastern Slovakia were found predispositions of this kind. These territories are characterized by the significant discrepancy in electoral results between urban and rural area, the rapid increase of this heterogeneity in time or simultaneous effect of both these factors.

On the other hand, the region of Horehronie, eastern part of Liptov region, north-eastern Slovakia and some (especially populationally and geographically smaller) regions located in the western half of the state (Skalica and Holíč, Zlaté Moravce, Nové Mesto nad Váhom and Dunajská Streda) have emerged as the regions with the lowest potential to become a hub of socio- political cleavage between urban and rural voters. A very similar electoral behaviour of urban and rural inhabitants is typical for these areas. A high degree of alikeness in voting pattern of urban and rural space, increase in this similarity or common action of both factors have been erasing the socio-political conflict line between these two environments. At the same time, this creates a frame for maintaining the phenomenon of differences in the electoral choices of urban and rural residents to be at a relatively low level also in the future.

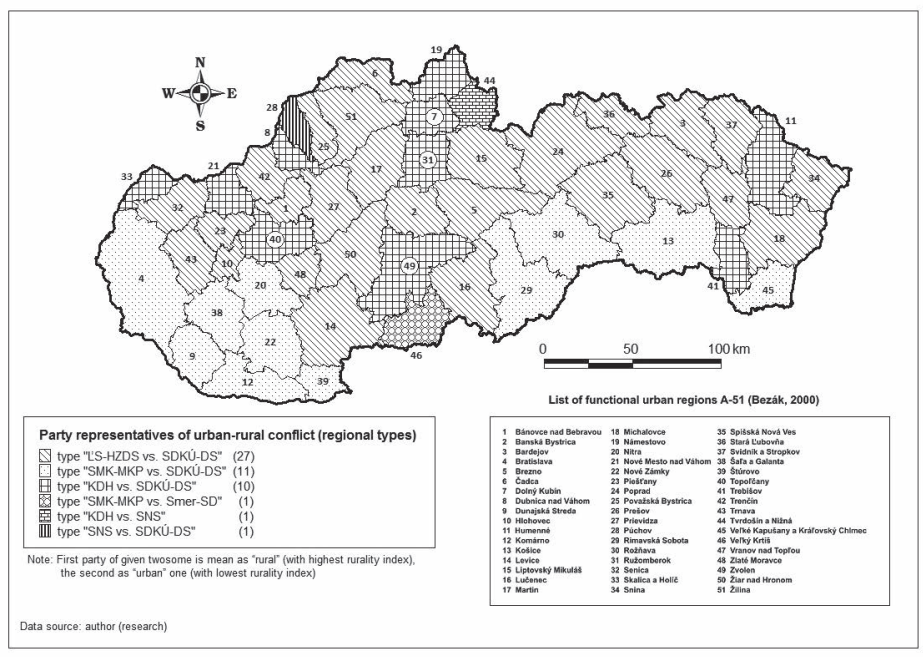

Fig. 3 Typization of Slovak regions according to long-term party representatives of socio-political urban-rural conflict based on parliamentary election results in period of 1998 2010 
Tab.1 Size, acceleration and potential of socio-political urban-rural conflict in Slovak regions in period of 1998-2010

\begin{tabular}{|c|c|c|c|c|c|c|c|c|c|c|c|c|c|c|}
\hline \multirow[b]{3}{*}{ Region } & \multicolumn{7}{|c|}{ SIZE and ACCELERATION } & \multicolumn{7}{|c|}{ POTENTIAL } \\
\hline & \multirow{2}{*}{$\begin{array}{c}1998 \\
\text { Size of } \\
U-R \\
\text { Conflict }\end{array}$} & \multirow{2}{*}{\begin{tabular}{|c|}
2002 \\
Size of \\
$U-R$ \\
Conflict \\
\end{tabular}} & \multirow{2}{*}{\begin{tabular}{|c|}
2006 \\
Size of \\
$U-R$ \\
Conflict \\
\end{tabular}} & \multirow{2}{*}{\begin{tabular}{|c|}
2010 \\
Size of \\
U-R \\
Conflict
\end{tabular}} & \multicolumn{3}{|c|}{$1998-2010$} & \multicolumn{2}{|r|}{ RM } & \multicolumn{2}{|c|}{ PM } & \multicolumn{2}{|c|}{ FCM } & \multirow[b]{2}{*}{$\begin{array}{l}\text { Average } \\
\text { ranking }\end{array}$} \\
\hline & & & & & \begin{tabular}{|c|} 
Size of \\
$U-R$ \\
Conflict
\end{tabular} & \begin{tabular}{|c} 
Acceleration \\
of U-R \\
Conflict*
\end{tabular} & \begin{tabular}{|c} 
Acceleration \\
of U-R \\
Conflict**
\end{tabular} & $d 1$ & Ranking & $d 2$ & Ranking & $d 3$ & Ranking & \\
\hline Vel'ký Krtíš & 10,174 & 4,698 & 5,671 & 12,923 & 8,367 & 1,27 & 1,32 & 13 & 1 & 67,45 & 1 & 3,083 & 1 & 1,0 \\
\hline Šal'a a Galanta & 2,618 & 1,942 & 2,142 & 3,472 & 2,544 & 1,33 & 1,16 & 13 & 2 & 33,42 & 4 & 0,815 & 4 & 3,3 \\
\hline Humenné & 0,710 & 1,489 & 1,200 & 0,996 & 1,099 & 1,40 & 1,24 & 18 & 3 & 25,84 & 8 & 0,317 & 8 & 6,3 \\
\hline Rožňava & 2,279 & 1,251 & 1,470 & 2,526 & 1,881 & 1,11 & 1,15 & 27 & 8 & 26,47 & 6 & 0,329 & 7 & 7,0 \\
\hline Spišs ká Nová Ves & 0,721 & 0,723 & 0,841 & 1,221 & 0,876 & 1,69 & 1,21 & 31 & 11 & 28,50 & 5 & 0,524 & 5 & 7,0 \\
\hline Rimavská Sobota & 1,561 & 1,282 & 1,333 & 1,883 & 1,515 & 1,21 & 1,09 & 22 & 4 & 25,63 & 9 & 0,283 & 10 & 7,7 \\
\hline Štúrovo & 0,944 & 0,904 & 1,031 & 1,313 & 1,048 & 1,39 & 1,12 & 23 & 6 & 25,38 & 10 & \begin{tabular}{|l|}
0,285 \\
\end{tabular} & 9 & 8,3 \\
\hline Senica & 0,763 & 1,118 & 1,044 & 1,068 & 0,998 & 1,40 & 1,14 & 26 & 7 & 25,19 & 11 & 0,273 & 11 & 9,7 \\
\hline Trebišov & 0,265 & 0,692 & 0,407 & 0,964 & 0,582 & 3,64 & 1,86 & 51 & 26 & 53,48 & 2 & 2,389 & 2 & 10,0 \\
\hline Nové Zámky & 1,250 & 1,131 & 0,893 & 1,554 & 1,207 & 1,24 & 1,14 & 22 & 5 & 24,29 & 13 & 0,197 & 13 & 10,3 \\
\hline Nitra & 7,246 & 5,081 & 6,535 & 2,407 & 5,317 & 0,33 & 0,79 & 52 & 27 & 36,34 & 3 & 0,910 & 3 & 11,0 \\
\hline Tvrdošín a Nižná & 0,832 & 0,948 & 1,069 & 1,136 & 0,996 & 1,37 & 1,11 & 29 & 10 & 24,71 & 12 & 0,237 & 12 & 11,3 \\
\hline Čadca & 0,504 & 0,683 & 0,689 & 0,807 & 0,671 & 1,60 & 1,18 & 49 & 22 & 26,02 & 7 & 0,349 & 6 & 11,7 \\
\hline Michalovce & 0,988 & 1,198 & 1,186 & 1,178 & 1,138 & 1,19 & 1,07 & 27 & 9 & 23,18 & 16 & 0,118 & 16 & 13,7 \\
\hline Levice & 0,793 & 1,020 & 1,069 & 1,030 & 0,978 & 1,30 & 1,10 & 33 & 14 & 23,70 & 14 & 0,164 & 14 & 14,0 \\
\hline Dolný Kubín & 0,842 & 1,105 & 1,165 & 1,021 & 1,033 & 1,21 & 1,08 & 33 & 13 & 22,85 & 18 & 0,098 & 18 & 16,3 \\
\hline Pieštany & 0,994 & 1,278 & 1,068 & 1,147 & 1,122 & 1,15 & 1,07 & 32 & 12 & 22,57 & 19 & 0,073 & 19 & 16,7 \\
\hline Púchov & 0,761 & 0,825 & 0,798 & 0,995 & 0,845 & 1,31 & 1,10 & 42 & 17 & 23,00 & 17 & 0,117 & 17 & 17,0 \\
\hline Zvolen & 0,534 & 0,797 & 0,701 & 0,749 & 0,695 & 1,40 & 1,15 & 49 & 21 & 23,41 & 15 & 0,154 & 15 & 17,0 \\
\hline Komárno & 0,985 & 0,921 & 1,044 & 1,141 & 1,023 & 1,16 & 1,05 & 38 & 15 & 22,03 & 20 & 0,037 & 20 & 18,3 \\
\hline Považská Bystrica & 1,050 & 1,089 & 1,136 & 1,064 & 1,084 & 1,01 & 1,01 & 40 & 16 & 20,40 & 23 & $-0,086$ & 24 & 21,0 \\
\hline Topol'čany & 0,706 & 0,966 & 1,052 & 0,818 & 0,886 & 1,16 & 1,08 & 46 & 19 & 21,22 & 22 & $-0,016$ & 22 & 21,0 \\
\hline Dubnica nad Váhom & 0,825 & 0,991 & 1,076 & 0,872 & 0,941 & 1,06 & 1,03 & 49 & 20 & 20,14 & 26 & $-0,099$ & 25 & 23,7 \\
\hline Hlohovec & 0,589 & 0,804 & 0,541 & 0,742 & 0,669 & 1,26 & 1,14 & 60 & 34 & 21,32 & 21 & 0,000 & 21 & 25,3 \\
\hline Trenčín & 0,973 & 1,212 & 1,058 & 0,910 & 1,038 & 0,93 & 0,99 & 45 & 18 & 19,04 & 29 & $-0,185$ & 29 & 25,3 \\
\hline Bratislava & 3,698 & 2,649 & 3,026 & 1,202 & 2,644 & 0,33 & 0,75 & 54 & 28 & 20,27 & 24 & $-0,165$ & 27 & 26,3 \\
\hline Námestovo & 0,920 & 1,110 & 0,930 & 0,902 & 0,965 & 0,98 & 1,01 & 50 & 23 & 19,25 & 28 & $-0,166$ & 28 & 26,3 \\
\hline Poprad & 0,746 & 0,795 & 0,842 & 0,838 & 0,805 & 1,12 & 1,04 & 60 & 33 & 20,24 & 25 & $-0,085$ & 23 & 27,0 \\
\hline V. Kapušany a Kr. Chlmec & 0,872 & 0,730 & 0,693 & 0,943 & 0,809 & 1,08 & 1,05 & 61 & 36 & 19,70 & 27 & $-0,126$ & 26 & 29,7 \\
\hline Trnava & 0,791 & 0,981 & 0,853 & 0,758 & 0,846 & 0,96 & 1,00 & 58 & 31 & 18,21 & 30 & $-0,238$ & 30 & 30,3 \\
\hline Prešov & 0,935 & 0,942 & 0,871 & 0,853 & 0,900 & 0,91 & 0,97 & 56 & 30 & 17,92 & 31 & $-0,262$ & 31 & 30,7 \\
\hline Lučenec & 1,275 & 1,322 & 0,950 & 0,978 & 1,131 & 0,77 & 0,93 & 51 & 25 & 17,29 & 34 & $-0,318$ & 35 & 31,3 \\
\hline Žilina & 1,133 & 1,458 & 1,271 & 0,839 & 1,175 & 0,74 & 0,94 & 51 & 24 & 17,20 & 35 & $-0,328$ & 37 & 32,0 \\
\hline Bánovce nad Bebravou & 0,706 & 1,013 & 0,958 & 0,657 & 0,833 & 0,93 & 1,02 & 64 & 39 & 17,77 & 32 & $-0,270$ & 32 & 34,3 \\
\hline Ružomberok & 0,760 & 1,078 & 0,975 & 0,678 & 0,873 & 0,89 & 1,01 & 63 & 37 & 17,47 & 33 & $-0,294$ & 33 & 34,3 \\
\hline Prievidza & 0,857 & 1,098 & 0,893 & 0,730 & 0,895 & 0,85 & 0,97 & 61 & 35 & 17,04 & 37 & $-0,327$ & 36 & 36,0 \\
\hline Vranov nad Toplou & 0,789 & 0,898 & 0,744 & 0,715 & 0,786 & 0,91 & 0,98 & 72 & 40 & 17,14 & 36 & $-0,315$ & 34 & 36,7 \\
\hline Žiar nad Hronom & 0,663 & 0,835 & 0,714 & 0,603 & 0,704 & 0,91 & 0,99 & 74 & 41 & 16,71 & 38 & $-0,343$ & 38 & 39,0 \\
\hline Košice & 1,731 & 1,157 & 1,241 & 0,881 & 1,253 & 0,51 & 0,82 & 55 & 29 & 14,48 & 44 & $-0,533$ & 45 & 39,3 \\
\hline Martin & 1,016 & 1,179 & 0,952 & 0,762 & 0,977 & 0,75 & 0,92 & 64 & 38 & 16,14 & 40 & $-0,397$ & 40 & 39,3 \\
\hline Dunajská Streda & 0,770 & 0,810 & 0,836 & 0,653 & 0,767 & 0,85 & 0,95 & 77 & 43 & 16,23 & 39 & $-0,381$ & 39 & 40,3 \\
\hline Liptovský Mikuláś & 0,842 & 0,902 & 0,846 & 0,669 & 0,815 & 0,79 & 0,93 & 75 & 42 & 15,79 & 42 & $-0,416$ & 42 & 42,0 \\
\hline Nové Mesto nad Váhom & 0,750 & 0,793 & 0,661 & 0,636 & 0,710 & 0,85 & 0,95 & 77 & 44 & 15,89 & 41 & $-0,404$ & 41 & 42,0 \\
\hline Stará Ĺubovňa & 1,195 & 1,264 & 1,362 & 0,629 & 1,113 & 0,53 & 0,87 & 59 & 32 & 13,88 & 47 & $-0,571$ & 47 & 42,0 \\
\hline Snina & 0,660 & 0,730 & 0,565 & 0,553 & 0,627 & 0,84 & 0,95 & 85 & 48 & 15,26 & 43 & $-0,447$ & 43 & 44,7 \\
\hline Svidnik a Stropkov & 0,748 & 0,637 & 0,461 & 0,589 & 0,609 & 0,79 & 0,95 & 88 & 50 & 14,47 & 45 & $-0,505$ & 44 & 46,3 \\
\hline Brezno & 0,947 & 1,044 & 0,840 & 0,543 & 0,843 & 0,57 & 0,85 & 78 & 45 & 12,92 & 48 & $-0,630$ & 48 & 47,0 \\
\hline Zlaté Moravce & 0,596 & 0,777 & 0,914 & 0,432 & 0,680 & 0,73 & 0,98 & 88 & 49 & 14,04 & 46 & $-0,540$ & 46 & 47,0 \\
\hline Bardejov & 1,152 & 1,004 & 0,547 & 0,610 & 0,828 & 0,53 & 0,84 & 81 & 47 & 12,23 & 49 & $-0,681$ & 49 & 48,3 \\
\hline Banská Bystrica & 0,903 & 1,126 & 0,880 & 0,469 & 0,844 & 0,52 & 0,85 & 80 & 46 & 12,18 & 50 & $-0,685$ & 50 & 48,7 \\
\hline Skalica a Holíc & 0,729 & 0,520 & 0,301 & 0,305 & 0,464 & 0,42 & 0,77 & 100 & 51 & 8,53 & 51 & $-0,939$ & 51 & 51,0 \\
\hline SLOVAK REPUBLIC & 1,643 & 1,388 & 1,595 & 0,767 & 1,348 & 0,47 & 0,82 & $\mathrm{x}$ & $\mathrm{x}$ & $\mathrm{x}$ & $\mathrm{x}$ & $\mathrm{x}$ & $\mathrm{x}$ & $\mathrm{x}$ \\
\hline SLOVAK REPUBLIC*** & 0,842 & 1,164 & 0,988 & 0,782 & 0,944 & 0,93 & 1,01 & $\mathrm{x}$ & $\mathrm{x}$ & $\mathrm{x}$ & $\mathrm{x}$ & $\mathrm{x}$ & $\mathrm{x}$ & $\mathbf{x}$ \\
\hline
\end{tabular}

Abbreviations:

U-R urban-rural $\quad$ RM ranking method

d1 integral indicator $1 \quad P M$ point method

d2 integral indicator 2 FCM factor comparison method

d3 integral indicator 3

* calculated as the growth rate of U-R conflict concerning the first and the last elections within the period under study (2010/1998),

** calculated as the average of three inter-electoral growth rates of U-R conflict $(2002 / 1998 ; 2006 / 2002 ; 2010 / 2006)$,

*** calculated without 11 regions with more than $20 \%$ share of Hungarians in order to eleminate an influence of ethnicity

Data source: author (research) 


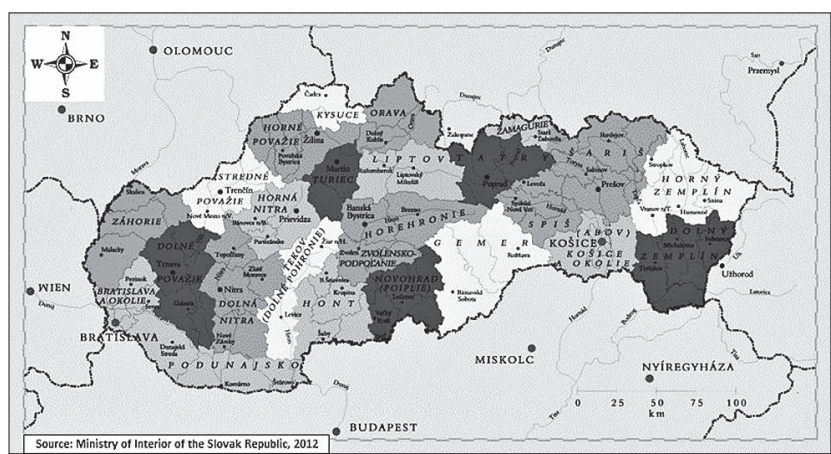

Fig. 4 Historical regions in Slovakia

\section{Conclusion}

In terms of voting preferential urban-rural dimension, the most notable socio-political cleavage were found in the regions of Vel'ký Krtíš, Nitra, Bratislava, Šala and Galanta, Rožňava and Rimavská Sobota. Conversely, the most similar election results between urban space on one side and rural communities on the other were registered in the regions of Skalica and Holíč, Trebišov, Svidník and Stropkov, Snina, Hlohovec, Čadca, Zlaté Moravce, Zvolen, Žiar nad Hronom and Nové Mesto nad Váhom. Thus, the nature of electoral support manifested by the rural and urban electorate can be regarded as a significantly different in several regions of southern and south-western Slovakia, whereas a very similar in some border regions of eastern Slovakia, in the region of Podpolanie, in north of Hont region and Tekov region located in the central part of the country, in Kysuce region and in populationally and territorially smaller regions lying in the west of the state.

In the period under study, the socio-political cleavage between the town and countryside deepened the most significantly in the regions of Trebišov, Spišská Nová Ves and Humenné located in eastern Slovakia, of Čadca, Tvrdošín and Nižná situated in the northwest, in Zvolen and its catchment area lying in the central part of the republic and in the western regions of Senica, Stúrovo, Šala and Galanta, where discrepancy between urban and rural electoral outcomes increased by more than a third. In the region of Trebišov, this conflict increased even by 3.5 times. On the contrary, the most significant decline in this cleavage occurred in the regions of Bratislava, Nitra, Skalica and Holic c located in the west of the country, of Banská Bystrica and Brezno situated in the central Slovakia and of Košice, Stará Lubovňa and Bardejov, which can be found in the eastern part of the republic. The regions of Trenčín, Považská Bystrica and Dubnica nad Váhom lying in the middle Považie, the western regions of Bánovce nad Bebravou and Trnava, the regions of Vranov nad Toplou, Prešov, Vel'ké Kapušany and Královský Chlmec situated in the eastern part of the country, Orava's region of Námestovo, and Žiar nad Hronom with its catchment area located in central Slovakia can be considered as the territories showing a relatively stable level of socio-political cleavage between urban and rural population expressed by the electoral votes coming from the town and countryside.

During the parliamentary elections held in period of 1998-2010, the regional type of Mečiar's L'S-HZDS (rural) and Dzurinda's SDKÚ-DS (urban) embodying the greatest long-term issue and value rivals within Slovak domestic and foreign policy affairs profiled as the most numerous party representatives' kind of socio-political conflict between rural and urban areas at the regional level. In this period, a massive shift of L'S-HZDS's voters to electorate of Smer-SD was registered, which transformed a previously weak urban profile of Robert Fico's party into slightly rural with expectation on further strengthening of its rurality.

Particular regions of southern and south-western Slovakia are regarded as the territorial units with the highest potential to be the future centres of social cleavage based on differential political inclination of urban and rural voters. Remarkable discrepancy in election outcomes between the votes cast in the town and countryside, the sharp increase of this dissimilarity during the period under study or common influence of both these factors are peculiar to these areas. The Horehronie region, the eastern part of Liptov region, north-eastern Slovakia and some (mainly populationally and geographically smaller) regions located in the west of the country emerged as regions with the lowest potential to become a socio-political conflict between urban and rural voters. A very similar political behaviour of urban and rural inhabitants is distinctive for these territories. A high level of correspondence in voting pattern between the town and countryside, continual strengthening of this similarity or operating of both factors have weakened the socio-political conflict line existing between the two environments under study. This means predispositions for maintaining the phenomenon of discrepancy in the electoral preferences of urban and rural population at a relatively low level in upcoming years. However, if we consider the socio-political cleavage between the town and countryside in Slovakian space-time context, we should not forget to mind influence of ethic structure (mainly in the case of SMKMKP and topically Most-Híd) and other conflict lines on final division of votes into urban and rural. Ongoing process of suburbanisation may also cause urban-rural pattern of electoral outcomes.

\section{REFERENCES}

BEZÁK, A. (2000): Funkčné mestské regióny na Slovensku. Bratislava: Geografický ústav Slovenskej akadémie vied. Geographia Slovaca, Vol. 15, pp. 7-89.

JOHANNSEN, L. (2003): The foundation of the state: emerging urban-rural cleavages in transition countries. Communist and Post-Communist Studies, Vol. 36, No. 3, pp. 291-309. 
KOSTELECKÝ, T., ČERMÁK, D. (2004): Metropolitan Areas in the Czech Republic: Definitions, Basic Characteristics, patterns of Suburbanisation and Their Impact on Political Behaviour. Praha: Sociologický ústav Akademie věd České republiky.

KRIVÝ, V. (1999): Územné celky a skupiny obcí v parlamentných vol'bách 1998. Sociológia, Vol. 31, No. 1, pp. 51-77.

KRIVÝ, V. (2000): Politické orientácie na Slovensku - skupinové profily. Bratislava: Inštitút pre verejné otázky.

KYLOUŠEK, J. (2007): Aspekty politologického výzkumu v městských aglomeracích. European Electoral Studies, Vol. 2, No. 2, pp. 185-193.

LEMEL, H. (1998): Rural land privatization and distribution in Albania: evidence from the field. Europe-Asia Studies, Vol. 50, No. 1, pp. 121-140.

LERMAN, Z. (1999): Agriculture in ECE and CIS: from common heritage to divergence. Land Policy Paper. Washington, DC: World Bank Land Policy Network.

LIPSET, S. M., ROKKAN, S. (1967): Party Systems and Voter Alignments: Cross -national Perspectives. London: Collier-Macmillan.

MADLEŇÁK, T. (2012): Regionálna diferenciácia volebného správania na Slovensku (1998-2010). Bratislava: Veda.

PINK, M., KYLOUŠEK, J. (2009): Voličská základna sociálnědemokratických stran v bývalém Československu a její prostorové proměny. European Electoral Studies, Vol. 4, No. 1, pp. 1-21.

SHABAD, G., SLOMCZYNSKI, K. M. (1999): Political identities in the initial phase of systemic transformation in Poland: A test of the Tabula Rasa hypothesis. Comparative Political Studies, Vol. 32, No. 6, pp. 690-723.

STOLL, H. M. (2004): Social Cleavages, Political Institutions and Party Systems: Putting Preferences Back into the Fundamental Equation of Politics. Stanford, CA: Department of Political Science, Stanford University.

SWINNEN, J. F. M. (1999): The political economy of land reform in Central and Eastern Europe. Economics of Transition, Vol. 7, No. 3, pp. 637-664.

VÝSLEDKY VOLIEB DO NÁRODNEJ RADY SLOVENSKEJ REPUBLIKY 1998: Bratislava: ŠÚ SR, 1998, available at: http://app .statistics.sk/volby98/default.htm (access 24. 3. 2012).

VÝSLEDKY VOLIEB DO NÁRODNEJ RADY SLOVENSKEJ REPUBLIKY 2002: Bratislava: ŠÚ SR, 2002, available at: http://app .statistics.sk/volby2002/default.html (access 5. 4. 2012).

VÝSLEDKY VOLIEB DO NÁRODNEJ RADY SLOVENSKEJ REPUBLIKY 2006: Bratislava: ŠÚ SR, 2006, available at: http://app .statistics.sk/nrsr_2006 (access 9. 4. 2012).

VÝSLEDKY VOLIEB DO NÁRODNEJ RADY SLOVENSKEJ REPUBLIKY 2010: Bratislava: ŠÚ SR, 2010, available at: http://app .statistics.sk/nrsr_2010/index.jsp (access 17.4. 2012).

ZARYCKI, T. (2000): Politics in the periphery: Political cleavages in Poland interpreted in their historical and international context. Europe-Asia Studies, Vol. 52, No. 5, pp. 851-873.

ZARYCKI, T., NOWAK, A. (2000): Hidden dimensions: the stability and structure of regional political cleavages in Poland. Communist and Post-Communist Studies, Vol. 33, No. 3, pp. 331-354.

\section{RÉSUMÉ}

\section{Regionální dimenze socio-politického konfliktu mezi městem a venkovem na Slovensku}

Politické chování občanů je tradičně formováno širokou plejádou faktorů, které ovlivňují jejich hlasování v samotných volbách.
Dichotomie prostoru i společnosti na město a venkov dlouhodobě generuje rozdílné volební výsledky. Klíčovým úkolem tohoto příspěvku bylo zachycení míry rurality volební podpory relevantních politických subjektů působících na slovenské politické scéně v období po přelomových volbách v roce 1998 až po rok 2010 nejen na národní, ale především na regionální úrovni. Evaluace úrovně a dynamiky sociopolitického štěpení společnosti venkova a města představovala jednu z nejvýznamnějších vědeckovýzkumných ambicí představované studie. Zhodnotili jsme postavení jednotlivých regionů Slovenska $\mathrm{z}$ hlediska rozsahu a akcelerace této konfliktní linie a pokusili jsme se o jejich kategorizaci na základě podobnosti hodnot ukazatelů charakterizujících tento společenský nesoulad. Komentovali jsme volební úspěšnost jednotlivých politických stran $\mathrm{v}$ městském a venkovském prostředí a na základě zjištěných reálii jsme zkoncipovali typizaci regionů Slovenska podle politických reprezentantů urbánního a rurálního prostoru. V závěru jsme vyhodnotili potenciál jednotlivých regionů ve smyslu budoucích ohnisek latentního štěpení společnosti projevujícího se v politických inklinacích jednotlivých částí země.

Při hodnocení globálního stavu zkoumané problematiky lze konstatovat, že mezi lety 1998 až 2010 došlo na celonárodní úrovni $\mathrm{k}$ volebně-preferenční konvergenci urbánního a rurálního prostředí. K nejcitelnějšímu sociopolitickému štěpení společnosti na bázi diference volebních preferencí obyvatel měst na jedné straně a venkovských obcí na straně druhé došlo v přelomových parlamentních volbách v roce 1998. Naopak nejvyšší míru podobnosti volebních výsledků mezi urbánním a rurální prostředím bylo možné evidovat u príležitosti voleb do NR SR uskutečněných v roce 2010. Výsledky provedeného výzkumu tak dokazují, že parlamentní volby v roce 1998 se právem označují jako souboj města a venkova, resp. jako vítězství urbánní části voličů nad rurální, což jen potvrzuje výraznou vyhraněnost politických inklinací těchto specifických prostředí právě v př́padě voleb před 15 lety. Druhá nejvyšší sociopolitická divergence mezi populací města a venkova byl registrován při volbách do NR SR v roce 2006, kdy se po osmi letech pravicové vlády dostal k moci někdejší vládní trojlístek Smer-SD, L’S-HZDS a SNS V tomto období je zajímavý masivní přesun elektorátu LS-HZDS $\mathrm{k}$ voličské základně Smeru-SD, což v konečném důsledků transformovalo původně nevýrazný urbánní profil strany Roberta Fica na mírně rurální s předpokladem dalšího posilování rurality její volební podpory. Pokud bychom však neuvažovali o společensko-politickém štěpení urbánního a rurální prostoru v jižních oblastech Slovenska typických vysokou územní koncentrací obyvatelstva madarské národnosti, které je dáno v první řadě geografickou kompozicí etnických skupin zdejší populace, pak bychom mohli za nejvýznamnější souboj skutečných městských a venkovských hodnot považovat ten odehrávající se ve volbách v roce 2002.

Obecně platí, že hodnotový rozpor mezi městem a venkovem projevený prostřednictvím specifického politického chování jejich obyvatel byl nejvýraznější v těch regionech země, v nichž žije vysoký podíl občanů madarské národnosti, a to především $\mathrm{v}$ jejich venkovském prostoru, přičemž urbánní prostředí těchto oblastí je charakteristické významným zastoupením populace slovenské národnosti. Avšak v této souvislosti je třeba zdůraznit, že vysoká ruralita volebních zisků SMK-MKP je vzhledem k prostorové kompozici jejího elektorátu zapříčiněna především etnickou strukturou obyvatel Slovenska charakterizovanou územní koncentrací občanů mad’arské národnosti v jižních částech země. Venkovský profil voličské podpory této strany se tedy programově neváže na prosazování hodnot a potřeb venkovské komunity jako takové.

Naopak nejmenší volebně-preferenční nesoulad mezi elektorátem měst a venkovských obcí byl zjištěn v těch částech Slovenska, které vykazují podobné sociální a ekonomické charakteristiky obou prostředí a nacházejí svůj politický rozměr ve volebních 
inklinacích samotného regionu bez zásadnějšího vlivu zkoumané konfliktní linie. Regionální obraz úrovně sociopolitického štěpení společnosti urbánního a rurální prostředí lze z prostorového hlediska považovat $\mathrm{v}$ rámci území Slovenské republiky za dlouhodobě platný. Rovněž můžeme předpokládat, že ke zmírňování společensko-politického rozporu mezi městem a venkovem přispívá relevantním dílem i probíhající proces suburbanizace největších měst Slovenska.

Martin Plešivčák

Comenius University, Faculty of Natural Sciences

Department of Human Geography and Demography

Mlynská dolina

84215 Bratislava 4

Slovak Republic

E-mail:plesivcak@fns.uniba.sk 